\title{
EXPLORING SACRED SPACE IN DIVIDED SOCIETIES: CAPE TOWN AND HAMBURG
}

\author{
Gordon Mitchell \\ University of Hamburg \\ Germany
}

\begin{abstract}
Peace-building and religious dialogue projects are increasingly experimenting with intercultural encounters in places such as mosques, churches or synagogues. It is assumed that such places have particular value for at least one of the parties and it is therefore anticipated that mutual visits will foster understanding and respect. It is customary to assume that first-hand exposure to other religions in the form of visits to mosques or churches, is an important means of developing cognitive as well as affective inter-religious competence. Opportunities to experience awe then become the task of Religious Education. Common to much of the literature on the subject is an almost essentialistic understanding of sacred space, which invests particular buildings with meaning. This article argues that what happens during such visits is even more complex. Space is sacred because people invest in it with meaning and this can happen in ways which are both fluid and fraught with inner contradiction. Encountering that space can therefore have a range of unanticipated consequences. Two initiatives where school pupils are encouraged to explore sacred space, one in Cape Town and one in Hamburg, will form the basis of this analysis.
\end{abstract}

Key Concepts: Sacred space, diverse understandings, visits, inner contradiction, respect

\section{The Pupil's Project in Cape Town}

The Didactics of Sacred Space, an emerging discipline within Religious Education, emphasises the need for proper preparation, sensitive implementation and thorough reflection afterwards. In many respects the Pupils' Project conducted in Cape Town in 1993, ${ }^{1}$ the year preceding the country's first democratic elections, is a model of good practice in this regard (Mitchell, 1995; Weisse, 1996). Ten years later, the group was invited to a reunion and the occasion was recorded audio-visually. ${ }^{2}$ During the week that followed individual interviews were used to determine both how they felt about their recent meeting and how they remembered the project of a decade earlier.

\section{The Project}

Eight young people had been invited to participate, all around twelve years of age and with religious identifications which reflected the major religions in South Africa: Protestant,

\footnotetext{
A project of the Institute for Comparative Religion in Southern Africa (ICRSA). It was co-ordinated by Gordon Mitchell, Sa'ddiyyah Shaikh and Masechaba Kakumbi. Project advisers were Nokuzola Mndende, Rashied Omar, Isabel Apahwo Phiri, David Chidester and Janet Stonier.

2 The research conducted by Kirsten Rüther and Gordon Mitchell was made possible by the generous support of the Deutsche Forschungsgemeinschaft, Sonderforschungsbereich 520: Umbrüche in Afrikanische Gesellschaften und ihre Bewältigung.
} 
Catholic, African Religion, African Independent Churches, Muslim and Hindu. The group had to be artificially constructed with participants from different residential areas as there was scant likelihood of finding a classroom with such diversity. Thus, for example, most Muslims and Hindus lived in coloured areas, most Jews in white suburbs and most members of African Independent Churches and practitioners of African Religion in the outlying townships (Flöel and Haferburg, 2002). Such spatial patterning of religion is the result of a long history of social inequality. From the late seventeenth century when slave quarters were shifted to the edges of the white settlement, the principle of separation has been applied. Apartheid ideology, legalised by the Group Areas Act of 1950, resulted in a tidying up of the ethnic landscape by means of forced removal to other areas for which their particular skin shade had been zoned. Thus the white suburbs are set on the lower slopes of Table Mountain, further away to the north-east, and separated by a busy highway, lies the coloured area, and beyond, the African townships of Langa and Gugulethu. Because the Western Cape had been zoned for whites and coloureds, black Africans were not supposed to be there at all. New arrivals, mainly from the rural Transkei, were unwelcome and confined to a precarious existence yet further out in informal settlements such as Crossroads.

Under such circumstances of colonisation, removal and resistance, investigation of sacred space in Cape Town is inevitably fraught with political meaning (Chidester, 2000). For their part, the project organisers had a sense that in which they were engaged, during those months before the transition to democracy, was not just a routine educational experiment, but a contribution to a dramatic turn in history. There would need to be educational material that would not only support the democratic ideal of equal respect for all, but in the very process of its composition would reflect that ideal. Thus, in line with the principles of People's Education (Christie, 1991), the content would need draw upon the religion of ordinary people who should themselves participate in the construction of knowledge (Mitchell, 1995). Thus pupils would themselves need to identify and interpret sacred space, from insider and outsider perspectives.

It was anticipated that each of the participants would have the opportunity of introducing the others to what she or he valued and prided. After all, it is human creativity that ascribes value and produces sacred space, and such a process would help to avoid the essentialistic assumption that each religion has certain things which are inherently sacred and which are always valued in the same way by everyone. An emphasis on children learning from children seemed to offer an opportunity to experience the fluidity and diversity of religion, each religion as a rainbow religion (Stonier and Derrick, 1997:1).

A considerable amount of travelling was involved in bringing the group together each time a visit was arranged. For close on two hours the hired mini-bus would move between the fine homes overlooking the Atlantic Ocean in Camps Bay, through the narrow streets of the Malay Quarter in Salt River and northwards on the airport highway to the Langa Township, with its matchbox houses and adjoining shantytown. The first visit was to the Claremont Main Road Mosque, which is located in a fashionable shopping centre and had managed to resist the efforts both of apartheid planners and of property developers. Over the years it had developed a reputation for a combination of liberal theology and political activism. ${ }^{3}$ Afterwards the group had lunch together at the home of Fathima, one of the Muslim pupils. ${ }^{4}$ This combination of religious building and home inevitably established a

Cf. The Claremont Main Road Mosque: Redrawing the Cape Tradition in Tayob, 1999:40-59.

The names of the participants have been changed for this article. 
pattern for the other visits: Hindu temple and Kogila's home, Dutch Reformed church and Maries's home, Orthodox synagogue and Peri's' home.

Planning was usually a complex process of tactful negotiation. It proved particularly so in the making of arrangements for the group to Langa township. Organisers felt that because of the limited physical space in the homes of Bonga, Andile and Themsi, it would be best to avoid a situation where they might be embarrassed. There was also the some degree of perceived physical risk for outsiders entering a township. The Roman Catholic Church Bonga sometimes attended was conveniently on the edge of the township. His mother and grandmother were there and the group was treated to the warm hospitality of the church community.

African Independent Churches are active in the poorest sectors of township society, services are conducted in the open air, and sacred space is in the centre of the circle of people engaged in worship. It was arranged to join Andile early on a Sunday morning when baptisms were to take place as the sun rose. The minibus drove through the deserted streets of Langa to meet with members of the church and then all travelled in convoy together to Seekoeivlei, a small lake situated between the white and the coloured areas. The visitors watched fascinated as the waters were first sanctified by the throwing of silver coins into the lake.

The ceremonies of African Religion are also not associated with specific religious buildings but are generally conducted in family settings. The dilemma of expecting Themsi to be the host and her not being in a position to invite the group to her home was dealt with by a shift of venue and focus. Nokuzola Mndende, project adviser and friend of the family, had recently moved into a new house in the white suburb of Rondebosch. She arranged for Themsi and her mother, both diviners in their own right, to conduct the customary ritual of cleansing there in what was perceived to be a safe and more spacious environment. The search for useful sacred space illustrates the way in which the sacred has not only moved from distant rural kraal to township but, with great political symbolism, also to the white suburb, in processes which may be called the migrating sacred (Chidester, 2000:16-19).

In follow-up meetings the pupils were able to process together what they had experienced and make plans for the next visit. The ideal of their selecting and explaining sacred symbols proved somewhat impracticable and was often modified by circumstances where adults, project organisers or local religious leaders, exercised significant influence. In their own subsequent evaluation of the project the participants felt that it had ended too soon, which not only suggests that they valued the learning experience but that they had needed more time to deal with issues which the visits had raised for them (Weisse, 1996).

\section{The Reunion}

At the start of the 10 year reunion, held on a Sunday afternoon in March 2003, there was a certain amount of shyness which was to be anticipated. In the intervening years there had only been contact between a few of them, those from Salt River had kept track of each other, Peri, Ibrahim and Marie had seen each other on the university campus, and Bonga and Andile saw each other frequently in Langa. Everyone had lost touch with Themsi, who no longer lived in Langa. The meeting was deliberately left unstructured, and as they greeted one another the spontaneous first question was: And, what are you doing now? One was in was in the final year of an Information Systems degree at the University of Cape Town, another busy with a postgraduate law degree. Marie was in London doing a practical as the final part of her Architecture degree and Fathima told of her exciting job working in 
the Cape Town office of an Irish Graphic Design firm. When he arrived, Bonga answered vaguely that he was still at high school, that Andile had dropped out of school and was working for his uncle as a taxi driver, and that Themsi and her mother had left the township and nobody knew what had become of her. ${ }^{5}$ All this information was left hanging in the air. In individual interviews afterwards, most made some reference to the striking discrepancies in personal circumstance and career prospects. For example, Peri described how she felt about the seeing the others again:

I just found that when you're eleven you're all the same and there are no differences between us, but now I was very conscious how everyone's lives had gotten and how, I don't know, just there were some serious splits there. When someone mentioned ... I don't remember his name, he's a bus driver, like stuff I would never have thought about. I kind of thought everyone was like me at that age, so they'd be more like me now, but everyone's lives have gone very differently, ... I think the differences between us are more obvious than then ten years ago ... I felt so conscious of where I am in my life, you know, it's a whole economic divide, it's not a race thing or a religious thing.

Not unexpectedly, given the original objectives of the Pupils' Project, conversation at the reunion turned to the topic of religion. Most made a point of emphasising how their opinions had shifted over the years. For Peri this was explained by means of distinction between religion and spirituality, and that the latter was what she understood to be her chosen focus. Fathima made a similar distinction, between tradition and religion. Tradition meant the meaningless rules and expectations imposed on her but which she did not find necessarily part of what she considered religion. She wanted herself to be seen as a modern person, with a career and a cross-section of friends. She, and not her elder brother, would decide what she understood by religion. The most detailed and vivid accounts of growing up in a changing society came from Bonga. What made it so fascinating was the gentle irony accompanying what he described. Whereas the horizons of the others had expanded to the university and the exciting world of work, his was still the township and the high school. One of the first things he did was to apologise for his English, adding: Under Bantu Education things had been better: Even our parents speak better, they know English and Afrikaans. Bantu education, usually seen as one of the despicable features of apartheid, is then even better than his experience of education in subsequent years! At the end of the meeting when cell-phone numbers and e-mail addresses were being exchanged by everyone else, he commented wryly, I don't have an e-mail, don't have a website. And when it was time to leave he asked to take some of the remaining snacks with him, with the remark, we need food in the township.

With evident pride he spoke of his initiation into manhood, which involved weeks in an isolated initiation school where he and other young men of his age were taught Xhosa tradition. He received a new name and was now expected to live with the dignity of an adult man. His chosen identity is a hybrid one. I go to the Roman Catholic Church, but I am a black. We do our traditional things - we talk to our ancestors. You see I am a man now. When you go to initiation school, your ancestors know who you are. His mother is Tswana and his father Xhosa. His mother is Roman Catholic and his father a member of the

The quality of education in township schools has remained appallingly low as the result of years of neglect under an apartheid system. Thus in 1998/9, for every R1 per capita expenditure on education for someone classified African, there was R1.86 for Coloured, R3.15 for Asian and R4.39 for White (Christie, 1991:110). With poorly trained and motivated teachers and inadequate facilities, desperate parents in the townships of Cape Town would move their children from school to school (cf. Ramphele, 2002:87-101). In the interview with Bonga in 2003, he reported having changed schools five times. 
Shembe church. My father goes to Shembe. He believes in Zulu guys, but I'm a Xhosa. To go to church he must go to Kwazulu-Natal. They say Shembe is the way, but I don't know which way. In the interview he goes into considerable detail about African Religion, healing and the crucial role of ancestors. ${ }^{6}$ He also told of how he and Andile had been to Themsi's mother for counselling. For the pupils from Langa, who had been neatly categorised into Catholic, African Independent Church and African Religion, the idea of one person per sacred space runs counter to the lived reality of what might be termed the hybrid sacred (Chidester, 2000:19-23). The boundaries between religions become porous as people insist on multiple religious affiliations and spaces.

\section{Divided Sacred Space}

The considerable socio-economic disparities in the present circumstances of pupils was strikingly brought home by the reunion. It could be expressed as I was surprised, or it was kind of strange to see everyone again or in Bonga's gentle irony. In these individual interviews, when describing the past experience most make brief reference, albeit obliquely, to the houses where people lived. For those who had co-ordinated the original project the reunion revived recollections of discomfort and soul-searching at the time:

(S)uch complete differences between people's realities, ... one was at Camps Bay another visit to

Langa, and ... looking at very impoverished communities and extremely well-off communities.

And I mean part of my dilemma, having done that project, ... was just, was it fair at some level to

take children from, you know, such completely impoverished communities, to such excessively

wealthy communities? (Sa'ddiyyah Shaikh, 2003).

The feelings associated with crossing the boundaries was something vividly recalled. Normally, the Langa pupils were the last to be dropped off but on one occasion it happened the other way around. Sa'ddiyyah recalls: I remember thinking ... it's very clear I'm not black, and Gordon's not black ... and we've got these kids here, and it was really a time, you know, the Amy Biehl kind of era. ${ }^{7}$ However, for those from Langa, the place that some fear, was home. In the interview with Bonga it is my township, my location, it is a place of which he is proud. There is not the corruption like in other townships ... even overseas tourists visit ... even if you are white you can walk in Langa ... it's like okay, it's a multiracial place you see ... in Langa, people they are friendly. Even though he would later talk about the gangsterism of his generation, he emphasises that it's only really dangerous to go into another township. In the interview he recalls feelings of fear when a group of young coloureds had come walking towards him one day when he happened to be in another township. He also describes an incident that had occurred in a white suburb, in fact on the way to the reunion! A white woman came walking along the road and when she saw him she crossed to the other side and shifted her handbag to the other shoulder. I felt my colour ... colour is the problem in South Africa, if you are black, ja, you are in trouble, you see, to white people....

6 The transition to democracy led to a revived public status of African Religion. Instead of suffering under the label of primitive it had become a source of pride, cf. Mndende, 1993; 1999.

7 During the course of the project, on 25 August 1993, Amy Biehl, a young American exchange student visiting a neighbouring township, was stabbed to death by a group of Pan-Africanist congress youth chanting one settler one bullet. 


\section{Travelling Sacred Space}

At the reunion, in the midst of some ambivalent rememberings of the past, there was also the conviviality of shared experience. They remembered eating ice-cream together at Marcell's in Rondebosch. The Pupils' Project was pretty interesting ... if you stay in a community like Salt River (Fathima), it was impressive because we were from such different backgrounds and we all got on (Peri), and the experience was a complete culture shock, like going from High School to University (Ibrahim). Even though disillusioned about what had become of the ideal of the Rainbow Nation, Bonga recalls with nostalgia those early experiences in the group. He remembers climbing trees with Andile in the gardens of some of the homes visited. He also recalls the project as an ideal: Like we were still young at that time, but we were always together in a taxi to travel from ... to Langa, dropping us, we were always together, and at least, my English was a lot better.

For the organisers the exercise was certainly driven by an idealism: I really believed in it. I had a lot invested in it (Sa'ddiyyah, 2003). Parents shared in this optimism that the project was all part of creating a new kind of society. Sa'ddiyyah recalls: Most of the parents were very receptive to the idea of this kind of intercultural inter-religious exposure, I think. To a certain extent the experiment created for all those involved - planners, parents and pupils - a sacred space of its own, one which continues to be imagined, idealised and remembered in all its ambivalence. The taxi moving across boundaries could not redraw these physically, but it could provide moments when it was possible to believe in an ideal human landscape where everyone has dignity.

In his conceptual analysis of sacred space David Chidester points out that it is necessary to recognise that it is people who allocate its meaning and that this always occurs within a political context (Chidester, 1994; 2000). Humans define sacred space in processes of claiming, protecting from defilement, and remembering its loss with nostalgia and longing. Sacred space of others can be strange and even dangerous, but the process of travelling across these boundaries creates a body of shared memory and hope. In a way this fragile, imaginative, and in the end profoundly ambivalent process of ascribing meaning occurred within the Pupils' Project. The experiences of encountering the other, being encountered by the other and seeing one's own sacred space through their eyes, and in the process creating a shared reality, all left lasting impressions. The longitudinal study of such phenomena raises a number of important questions for further research on the didactics of sacred space.

\section{Projekt Didaktik Heilige Orte, Hamburg}

A city of 1715 million people, Hamburg is one of the most culturally diverse areas in Germany. Roughly $25 \%$ are minorities, a number which includes the 86,000 ethnic German migrants from the former Soviet Union. There are 185 different nationalities in the city. Of the non-naturalised residents, 24\% are Turkish, 9\% Yugoslav, 7\% Polish, 6\% Afghani, 5\% Iranian. The result has been a complex and ever-changing landscape in which languages, religions and ethnic identifications continue to exercise influence. The majority Lutheran Church is concerned about what it perceives to be a loss of public influence, it remains the most prominent religious grouping, both in numbers and in the way its steeples shape the skyline. Over the past two decades there has been an active interest in promoting school visits to sacred spaces, both as a means of generating interest in the cultural heritage of the city and in fostering interreligious understanding. The field is well serviced with scholarly literature, particularly with regard to Kirchenpedagogik (Grünewald, 2003; Hansen, 1997; 
Steffensky, 2003) and Moscheepaedagogik (Özdil, 2002). Every month approximately thirty school classes visit a church, mosque, synagogue or temple. During the winter of 2004 eleven teams of student researchers accompanied school classes to monitor what was taking place. They observed body language, kept note of the teaching method and interviewed pupils before, during and after the visits.

A great deal of thought has gone into designing learning processes for classes visiting the large and impressive city churches of Hamburg. There is an emphasis on an initial, almost meditative process of experiencing the space. Time is allowed for the pupils to become aware of the quality of sound or the light illuminating the stained-glass windows. They are encouraged to wander around identifying and interpreting interesting symbols. They can further appreciate the architectural design by exercises in building arches with wooden blocks which are part of the available educational kit, or they can experience with their bodies what it feels like to be an arch by stretching their arms high and leaning onto a partner, supporting and being supported. The space is thus experienced with all senses. Not only is it an opportunity for minority pupils to engage with the religious (majority culture) of the city, but for most of the Protestant Christian pupils as well (cf. Hansen, 1997). One could continue describing the varied and fascinating examples of Kirchenpädagogik, but the purpose of this essay is to look for the seams in the story, its puzzles and its contradictions.

\section{Rebuilt Sacred Space}

The origins of many of the churches lie in the twelfth and thirteenth centuries and the influence of social, political and artistic change provides a fascinating opportunity for reflecting on the building diachronically. An observer can only be impressed by such a rich resource for historical, cultural and religious study. At the same time one thing which is noticeable is a tendency to overlook the sometimes massive damage to the buildings in World War Two. Thus pupils visiting a church in Billstedt which had been bombed during the war were instead told a very entertaining tale of the church being razed to the ground in the seventeen-hundreds. A meat-smoking shed nearby had caught alight and, when the fat from the bacon exploded, flames shot thirty metres into the sky and set fire to the roof of the church.

The steeple of St Nikolai at 147 meters was one of the highest in Germany. Located in the inner city it served in 1943 as the orientation target for the British Bomber Command in their saturation bombing programme aptly entitled Operation Gomorrah. After the war the ruined church was not rebuilt, but a new St. Nikolai was erected some kilometres away. The ruins are there to visit, but this potentially powerful story is avoided. Generally, when the subject of the destruction of the central part of Hamburg is dealt with it is done in such a way as to avoid any notion of Germans as victims. It is believed that such attitudes could provide a fertile ground for right-wing nationalism (cf. Grünberg, 2000:72).

\section{Migrating Sacred Space}

Those responsible for the programme in visits to mosques also seek to present a benign picture of the world. The Central Mosque near the main train station is the most frequently visited by school classes. Like the majority of mosques in the city it is located in a building originally built for other purposes, in this case a bathhouse. A fascinating reminder of the contrast with the ideal: A picture of a classical Turkish mosque has been painted on the side wall of the building. The first generation of migrants were workers (Gastarbeitern) and it 
had been anticipated that they would someday return to their homeland. A point made several times by the educator in explaining the significance of the rich interior decoration was that it was a sign that Muslims had come to stay in Hamburg. Visitors are rarely told of the struggles experienced by Muslim communities in obtaining official permission to hire or buy space for religious use in the city. Resistance by local residents is often supported by the municipality, particularly if the applicants are regarded as fundamentalist or propose plans which would change the cultural profile of the area. Such encounters over the acquisition of sacred space are widely reported in the local media. Thus when they wished to hire a former post office building in Veddel it was reported: Moschee statt Post? Bezirk sagt Nein (Hamburger Abendblatt:15 January 2004:13), or when application was made to refurbish a former steakhouse in Harburg, Senat entscheidet über Moschee. Bezirksversammlung Harburg bekräftigte Veto gegen Bauvorhaben (Hamburger Morgenpost: 29 January 2004:16). All of this must influence how people feel about sacred space. In an essay on this subject, Transportable Heimat, Wolfgang Grünberg draws attention to the way in which such strategies of symbolic exclusion have a far reaching social and psychological influence, both on minorities and on majorities (Grünberg, 2000).

Pupils, however, particularly those still in primary school, appeared to be unaware of such debates. They responded very positively to the warmth of human welcome which awaited them at the mosque: The small glasses of variously coloured teas, the comfort of under-carpet heating, the interesting stories. These became the points of comparison to what they had experienced elsewhere. Churches in contrast were old, cold and scruffy. High school pupils (and the university students observing their visits) were much more critical of their time in the mosque. Thus the comfort and decor of the men's prayer room was compared to the more frugal room reserved for women. In addition to negative perceptions of Islam for espousing male domination, its reputation as a violent religion was another issue. Since 11 September 2001 the picture of young men sitting in Hamburg mosques plotting death and destruction has remained a vivid one (Mitchell, 2003). Much continues to be made in the media of the nearby Al-Kuds Mosque where Mohammed Atta and his circle spent time. Soon after one of his associates, Abdelghani Mzoudi was released from prison he was photographed surrepticously entering that mosque. The newspaper report read, Mzoudi - auf dem Weg in die Al-Kuds-Moschee (Hamburger Abendblatt. 24/25 April 2004: 17). The caption at the foot of a photograph of him shielding his face with a briefcase reads: Am Ziel: Der Marokkaner verschwindet in der Al-kuds-Moschee, die sich im ersten Stock eines Büro-gebaudes befindet. Nur einige arabische Schriftzeichen weisen den Weg. Now the very fact of mosques being inobtrusive is cause for suspicion.

Just over half of the some 60 university students who themselves visited the Central Mosque were not satisfied with the attempts by the mosque educator to argue that Islam is neither a violent religion nor supportive of the subjugation of women. Little wonder that the manual (Özdil, 2002) written to prepare in-house educators, and based on over ten years of experience, devotes considerable attention to the subject of how a mosque educator should deal with critical questions. For insiders these mosques are a source of pride, they are identitätsfördernde Kristallisationspunkte (Grünberg, 2000:75), and for some outsiders they are a reminder of unwelcome foreigners, but for most citizens of this liberal city, the controversy is a painful reminder of the past. In Germany it is the synagogue that serves as an ever present archetype for discussion about the place of religious minorities within the society. 


\section{Guarded Sacred Space / Empty Sacred Space}

Visits to a synagogue in Hamburg are difficult to arrange as there is only one of its kind remaining in the city. Approaching the building, security precautions soon become evident. The entire street is sealed with barricades and there is the continuous presence of a special protection police unit armed with assault rifles. Inside the synagogue however things are very calm and normal, if not somewhat boring. The visit usually takes the form of a lecture by a retired teacher and pupils are not free to wander around, as they might have grown accustomed to from visits to other sacred sites. Nevertheless, from interviews with the pupils, it was clearly an important experience for the Grade 10 class, Eppendorfer Gymnasium. They had prepared themselves well with information about the meaning of symbols likely to be found in a synagogue as well as the history of the Jewish community in Hamburg. It was that history which gave particular value to what they were now doing.

Another Grade 10 class, this one from Rahlstedt, had chosen to visit the site of a former synagogue not far from the university. ${ }^{8}$ Hamburg's main synagogue was set alight and destroyed in 1938. The place where it stood is now called Carlebach Platz, an empty space. After the war it was decided not to rebuild and, by not doing so, to ensure that the memory was sustained. One of the Rabbis at the time had said: Let no grass grow between these stones. As their social project the school class undertook to ensure that the area was kept clean. When we first saw them at work on a very cold afternoon, what was immediately striking was that, from outward appearance, the majority of the class appeared to be foreign born. Indeed, it turned out that almost half of them were Muslim and many had a background as refugees. They were from Kosovo, Afghanistan, Croatia, Turkey and Armenia.

The central questions posed by researchers were: How did you experience the project?, and what debates had taken place in the process of deciding to undertake the project? Classroom discussion was recorded and analysed with the help of the pupils. Small groups and individuals were interviewed. Obviously, differences in perspective were to be expected. For the German nationals and their parents there seemed to be unanimous and articulate support for the project. If there were any covert neo-Nazis in the class they would at least have found it difficult to articulate their position in what was understood as an antifascism project. (The schooling system places pressure on pupils to take the history of the Holocaust seriously and dissidence on this matter is generally taken as a very grave matter.) The occasional negative comment based itself on arguments such as the inappropriate timing in the middle of a cold winter or their preference for alternatives which provided better working experience. Nevertheless, five months on it was clear from observation that the work was being taken much more seriously than at the beginning. In a second round of interviews most reported that the act of pulling out weeds and sweeping the cobblestones had been an experience which they valued. For some it served as a means of coming to terms with their own experience. As a pupil who had fled Afghanistan as a young girl said during one of the classroom discussions: When I think of Jews I think of Israel and I hate Jews. I'm a Muslim. But when I stand on that place I think of people who have been pushed around and I feel the same as them. This is a good project that we are doing. In the biographical interview she recalled her experience of fleeing Afghanistan as a young girl and described the abiding reality of her minority and migrant status in the society. The Jewish experience was thus very real for her.

8 The project was initiated by the class teacher, Thomas Berger. The research team consisted of Carolin Brandt, Katrin Putschbach, Christine Müller, Christian Scholz and Gordon Mitchell. 
In a recent study, Entliehene Erinnerung (Georgi, 2003), Borrowed Memory, attitudes of minorities in Germany to the history of nationalism and Holocaust are investigated. Many of the young people surveyed do indeed respond by identifying themselves with the plight of the Jews. They too feel themselves to be excluded and humiliated by the majority. It does seem that minorities in Germany are less likely to deny the Holocaust than might be the case elsewhere. To do so would be to put themselves in the same camp as the xenophobic neo-Nazis. It would also be difficult to deny an atrocity when there are classmates insistent on accepting liability for what had happened during the time of their grandparents. In the course of one of the classroom discussions in May 2004 there was a heated exchange between a German pupil and a pupil from Croatia who maintained that she in no sense needed to feel any kind of responsibility, while he insisted that the fact that she chose to make Germany her home meant that she had to accept that it was her past as well.

Empty sacred space can provide a setting where innocence and guilt are played out. It is a vivid reminder of inhumanity, of what Neville Dubow names absence as presence. In his essay Jewish Berlin and the Struggle of Memory (Dubow, 2001:47-68) Dubow recalls visiting places in Berlin where Jews once lived: Some streets away ... is a row of perfectly ordinary double-storied houses. One of them is missing, like a gap in a row of teeth (2001:65).

The selection of sacred sites by teachers planning visits seems to be guided by the principle of first exposing pupils to what is appealing and noble about a particular sacred site. The choice is not necessarily confined to religious buildings, but might include an ecology project or a laudable social initiative. Primary school pupils, it seems, do not seem to be bothered in the same way by the ironies and contradictions as is the case with their older peers and adults. For more mature pupils it can be an exploration of these that makes the investigation of sacred space so important a topic.

\section{Conclusions}

Perhaps there are contexts where sacred space does not evoke strong feelings, but certainly not in South Africa or in Germany. Both projects sought to understand how children might explore sacred space. It clearly means different things to different people. Sacred space can migrate, it can be hybrid, it can be empty. Meanings ascribed are changing and ambiguous. Their inherent subjectivity resists efforts to fix or finalise meaning. All this makes the educational task rather unpredictable. It is not only a question of different people seeing things differently. When they are there together, they encounter a space through the eyes of other people. They observe themselves as they imagine others might see them. This means that questions of social class, ethnicity and history become unavoidable aspects of interpretation. Using South Africa and Germany as case studies makes the point clearly that Religious Education cannot only be about the meaning of symbols in isolation, but includes how those meanings are rooted in particular social and historical contexts.

Such extreme histories can be explored in settings where everything is much milder and less apparent. In an essay entitled Homage to the Extreme Michael Bernstein (Bernstein, 1998) refers to the Holocaust as a novum, a rupture so decisive in the fabric of our common history that it fundamentally altered the terms within which we try to make sense of our experience. Apartheid has also provided the world with a vivid metaphor of inhumanity. Both deserve to be remembered not just because they happened but because they help to expose ways in which such crimes continue to occur. They also offer a narrative for education in human rights which reaches over national borders (cf. Brumlik, 2001). 


\section{BIBLIOGRAPHY}

Bernstein, Ml 1998. Homage to the Extreme - the Shoah and the rhetoric of catastrophe. Times Literary Supplement. March 6, 1998.

Böhme, G 1998. Atmosphären kirchlicher Räume. Kunst und Kirche. 2:9-12.

Brumlik, M 2001. Erziehung nach ‘Auschwitz' und Pädagogik der Menschenrechte. Eine Problemanzeige. Erziehung nach Auschwitz in der multikulturellen Gesellschaft. Pädagogische und soziologische Annäherungen, (eds.) Fechler, B, Kössler, G and Lieberz-Gross, T. Weinheim/München: Juventa. 47-58.

Chidester, D 1994. The poetics and politics of sacred space. Towards a critical phenomenology of Religion. Analecta Husserliana. XLIII:211-231.

Chidester, David 2000. Mapping the Sacred in the Mother City. Religion and Urban Space in Cape Town. Journal for the Study of Religio. 13(1\& 2) 5-41.

Christie, P 1991. The Right to Learn. The Struggle for Education in South Africa. Johannesburg: Ravan Press.

Dubow, N 2001. Imagining the Unimaginable. Holocaust Memory in Art \& Architecture. Cape Town: Kaplan Institute.

Flöel, C and Haferburg, C 2002. Spatial Patterns of Religions in Greater Cape Town. Religion and the Political Imagination in a Changing South Africa, (eds.) Mitchell,G \& Mullen E. Münster/New York: Waxmann. 207-220.

Georgi, V 2003. Entliehene Erinnerung. Geshichtsbilder junger Migranten in Deutschland. Hamburg: Hamburger Edition.

Grünewald, E2003. Kirchenpädagogik in der 'Kirche um die Ecke'. Arbeiten im bildlosen Raum. Kirchenpädagogik. 2:6-16.

Hansen, I 1997. Sprache finden. Kinder entdecken die fremde Kultur 'Kirche'. Hamburg als Chance der Kirche. Arbeitsbuch zur Zukunft der Kirche in der Grosstadt. Hamburg: EB Verlag. 302-311.

Klie, T 1998. Ecclesia quaerens paedagogiam. Wege zur Semantik heiliger Räume. Der Religion Raum Geben. Kirchenpädagogik und religiöses Lernen, (ed.) Klie, T. Hamburg. 5-17.

Mitchell, G 1995. "Grundsätze für den Neuaufbau religioes-ethischer Erziehung in den Schulen Südafrikas”. Das Project Weltethos in der Erziehung, (eds.) Lähnemann J. Hamburg: EBVerlag. 230-235.

Mitchell, G 2003. Terror Pilots as Neighbours. Talking about Violence, Religion and Dialogue in Hamburg after $11^{\text {th }}$ September". International Journal of Diversity in Organisations, Communities and Nations. 3:351-360.

Mndende, N 1993. African Traditional Religion in Schools? The End of the Tunnel. Religion Education for a non-racial South Africa, (eds.) Mitchell, G, Mndende, N, Phiri, I \& Stonier, J. Cape Town: ICRSA. 24-32.

Mndende, N1999. From underground praxis to recognized religion. Challenges facing African Religion. Religion and Politics in South Africa. From Apartheid to Democracy, (eds.) Tayob, A \& Weisse, W. Münster/New York: Waxmann. 91-98.

Özdil, Ali-Özgür 2001. Wenn sich die Moscheen öffnen. Moscheepädagogik in Deutschland. Münster/New York: Waxmann.

Ramphele, M 2002. Steering by the Stars - Being young in South Africa. Cape Town: Tafelberg. 
Steffensky, F 2003. Der Seele Raum geben Kirchen als Orte des Besinnung und Ermutigung. Hannover: Evangelische Kirche Deutschland.

Stonier, J, and Tracy, D 1997. Sacred Places. A New Approach to Religion Education for South African Primary Schools. Cape Town: Juta.

Tayob, A 1999. Islam in South Africa. Mosques, Imams, and Sermons. Gainesville: University Press of Florida.

Weisse, W 1996. Children Learning from Children. An interreligious school-project in the new South Africa: Stimulus for Religious Education in Germany. Methodologies, Conceptions and Pilot Projects in South Africa, Namibia, Great Britain, the Netherlands and Germany, Interrreligious and Intercultural Education, (ed.) Weisse W. Münster: Comenius Institut. 47-52. 